University of Nebraska - Lincoln

DigitalCommons@University of Nebraska - Lincoln

Marketing Department Faculty Publications

Marketing Department (CBA)

Summer 2009

\title{
Sales Buy-in of Marketing Strategies: Exploration of Its Nuances, Antecedents, and Contextual Conditions
}

Avinash Malshe

University of St. Thomas, Minnesota, amalshe@stthomas.edu

Ravipreet S. Sohi

University of Nebraska-Lincoln, ravisohi@unl.edu

Follow this and additional works at: https://digitalcommons.unl.edu/marketingfacpub

Part of the Marketing Commons

Malshe, Avinash and Sohi, Ravipreet S., "Sales Buy-in of Marketing Strategies: Exploration of Its Nuances, Antecedents, and Contextual Conditions" (2009). Marketing Department Faculty Publications. 20.

https://digitalcommons.unl.edu/marketingfacpub/20

This Article is brought to you for free and open access by the Marketing Department (CBA) at DigitalCommons@University of Nebraska - Lincoln. It has been accepted for inclusion in Marketing Department Faculty Publications by an authorized administrator of DigitalCommons@University of Nebraska - Lincoln. 


\title{
Sales Buy-In of Marketing Strategies: Exploration of Its Nuances, Antecedents, and Contextual Conditions
}

\author{
Avinash Malshe and Ravipreet S. Sohi
}

\begin{abstract}
This study uses a qualitative research design with the grounded theory method to explore the multifaceted nature of sales buy-in - that is, the sales function's belief that marketers' proposed strategy is appropriate and has merit. Based on 49 in-depth interviews with sales and marketing professionals, the findings indicate that obtaining sales buy-in consists of four key components: (1) objectivity and rational persuasion, (2) sensitivity and responsiveness to reality, (3) involvement in strategy creation, and (4) positioning for success. The findings also show that three organizationallevel factors play an important role in determining sales buy-in: (1) eliminating interfunctional walls, (2) bridging the cultural divide between sales and marketing, and (3) developing interfunctional relationships. Last, sales buy-in depends on two contextual conditions - hierarchy and strategy absorption time.
\end{abstract}

$\mathrm{T}$

he sales-marketing interface, which plays an important role in a firm's strategic processes, has recently started attracting scholars' attention (e.g., Dewsnap and Jobber 2000, 2002; Guenzi and Troilo 2007; Homburg and Jensen 2007; Homburg, Jensen, and Krohmer 2008). This stream of research indicates that when marketing and sales functions work well together, firms are in a better position to identify customer needs and deliver the desired customer value (Guenzi and Troilo 2007). Scholars further assert that for successful strategy creation and execution, these two functions need to be well aligned and integrated (Cespedes 1993, 1996; Piercy and Lane 2003; Rouziès et al. 2005).

However, the literature also indicates that conflict, noncooperation, and mutual negative stereotyping often exist between sales and marketing functions throughout the strategy formulation and implementation processes (Montgomery and Webster 1997). Further, scholars suggest that distrust and prejudices between these two functions make it difficult for one function to appreciate the other's role in the strategic process (Homburg, Jensen, and Krohmer 2008; Matthyssens and Johnston 2006). Specifically, in situations where marketing handles strategy creation activities independent of sales, salespeople may view the proposed marketing initiatives as ineffective or irrelevant (Aberdeen Group 2002; Dewsnap and Jobber 2000; Kotler, Rackham, and Krishnaswamy 2006; Rouziès et al. 2005). The down- stream effects of such independent approaches become readily apparent during strategy implementation when the sales function does not buy into, and wholeheartedly support, the strategies and initiatives proposed by marketing (Lorge 1999; Strahle, Spiro, and Acito 1996; Yandle and Blythe 2000).

The notion of sales buy-in, which we elaborate on further in the next section, reflects the sales function's belief that a proposed marketing strategy or initiative is appropriate and has merit. Several scholars have highlighted the need for organizational functions to support each other's initiatives (Dewsnap and Jobber 2000; Homburg and Pflesser 2000; Kohli and Jaworski 1990; Maltz and Kohli 1996; Narver and Slater 1990; Olson, Slater, and Hult 2005a, 2005b; Rouziès et al. 2005; Ruekert and Walker 1987; Srivastava, Shervani, and Fahey 1999; Varadarajan, Jayachandran, and White 2001). Yet there is no research on what makes the sales function buy into marketing's strategies and initiatives. The purpose of this paper is to fill this research gap by providing an understanding of (1) what constitutes the notion of sales buy-in of marketing strategies, and (2) what factors either determine buy-in, or influence whether marketers succeed in getting sales buyin. We do so by using the grounded theory method (Strauss and Corbin 1998), with 49 in-depth interviews of sales and marketing professionals.

Avinash Malshe (Ph.D., University of Nebraska-Lincoln) is Assistant Professor of Marketing, Opus College of Business, University of St. Thomas, MN; email amalshe@stthomas.edu

Ravipreet S. Sohi (Ph.D., University of Wisconsin, Madison) is Professor of Marketing, College of Business Administration, University of Nebraska-Lincoln; email rsohil@unl.edu

The authors acknowledge the suggestions made by Michael Krush and Eddie Nowlin on the earlier drafts of this paper. The authors also thank the three anonymous reviewers and the editor of Journal of Personal Selling \& Sales Management for their helpful comments. The first author acknowledges two grants for providing support for this research: Dean's Summer Research Grant, Opus College of Business and the Research Assistance Grant (RAG) from the Faculty Development Center - both at the University of St. Thomas, MN. 
This paper makes three specific contributions to the sales-marketing interface literature. First, it shows the complex nature of sales buy-in and explicates its various facets. Second, this paper outlines intraorganizational factors that influence sales buy-in. Third, the data show that sales buy-in depends on two contextual conditions - hierarchy and allowing salespeople adequate time to absorb the key strategic ideas. Our findings have several marketing implications that we discuss later in the paper.

\section{BaCKGROUND Literature AND Research Questions}

\section{Sales Buy-In}

We conceptualize sales buy-in as the sales function's belief that a proposed marketing strategy or initiative is appropriate and has merit.

Although the notion of buy-in may seem close to the idea of sales and marketing functions "being on the same wavelength," "being in sync with one another," or "sales function being on board" (Ahmed and Rafiq 2003; Cespedes 1996; Donath 1999; Kotler, Rackham, and Krishnaswamy 2006; Lings and Greenley 2005; Naudé, Desai, and Murphy 2003), it is different in that buy-in pertains to a specific marketing initiative. Buy-in is also different from compliance, where salespeople may be merely performing some activity because marketing has directed them to do so, even when they are not convinced about the initiative's merit or appropriateness. Further, sales buy-in differs from sales-marketing integration (Rouziès et al. 2005) in that the former focuses on salespeople's belief about a specific strategy proposed by their marketing colleagues, whereas the latter encompasses the overall extent to which activities carried out by each function are supportive of the other.

Two streams of literature-internal marketing and sales-marketing interface-provide the foundation for studying sales buy-in. Table 1 presents the salient perspectives from these two literature streams. As the following discussion highlights, internal marketing consists of a set of planned activities and efforts toward getting firm's frontline employees excited about the various strategic initiatives. The sales-marketing interface, on the other hand, deals with the macro-level issues at the interface between the two functions. The concept of sales buy-in serves as an important bridge between these two streams of literatures. Sales buy-in is a potential outcome of internal marketing initiatives and can help smooth the sales- marketing interface.

\section{Internal Marketing}

There are several definitions of internal marketing. As noted earlier, Table 1 highlights some important perspec- tives. Overall, scholars characterize internal marketing as a planned effort initiated within the firm, which aims to achieve strategic alignment between frontline employees and marketing using effective internal communication strategies. The extant body of literature in this area discusses the importance of internal marketing in trying to get frontline employees excited about and committed to firms' strategic initiatives (Ahmed and Rafiq 2003; Berry 1981; Lings and Greenley 2005; Sasser and Arbeit 1976; Wasmer and Brunner 1991). This literature, which is mainly conceptual, suggests that in addition to using internal communication, marketers may achieve alignment between themselves and an organization's frontline employees by using influence strategies or instituting cultural change (see Gounaris 2006 and Lings 2004 for extensive review). Scholars further suggest that internal marketing efforts may result in better interfunctional coordination, leading to increased commitment from frontline employees to organizational goals (Rafiq and Ahmed 1993; Tansuhaj, Randall, and McCullough 1988). In addition, the literature notes that the aim of internal marketing is to get frontline employees within a firm fully on board in the value creation process (e.g., Ahmed and Rafiq 2003; Lings and Greenley 2005; Naudé, Desai, and Murphy 2003).

\section{Sales-Marketing Interface}

The extant sales-marketing interface literature highlights how the interaction between these two functions is less than optimal (Montgomery and Webster 1997; Strahle, Spiro, and Acito 1996). Scholars have pointed to many problem areas that may afflict this interface. For example, researchers point to interfunctional conflicts, differences in goal orientation, tension regarding standardization and adaptation, and marketers' disconnectedness from market conditions as problem areas. Similarly, scholars indicate that turf barriers and differences in culture or thought worlds pose challenges within this interface and strain the relationships between sales and marketing (Beverland, Steel, and Dapiran 2006; Dewsnap and Jobber 2000, 2002; Homburg and Jensen 2007; Rouziès et al. 2005).

Given the acrimonious nature of this interface, extant research also highlights many factors that can allow the sales function to be supportive of marketing and vice versa. Specifically, Cespedes (1993) indicates that firms could institute or improve structural linkages, field marketing systems, and cross-functional processes to improve the coordination of activities between sales and marketing. Dawes and Massey (2006) and Massey and Dawes (2007) argue for cordial cross-functional relationships, whereas LeMeuneir-FitzHugh and Piercy (2007) stress the importance of sales-marketing collaboration, improved interfunctional communication, and reduced interfunctional conflict. Scholars also emphasize that better collaboration between sales and marketing can enhance a firm's ability to provide better customer value (Guenzi and Troilo 2007; 
Table I. Perspectives from Extant Literature

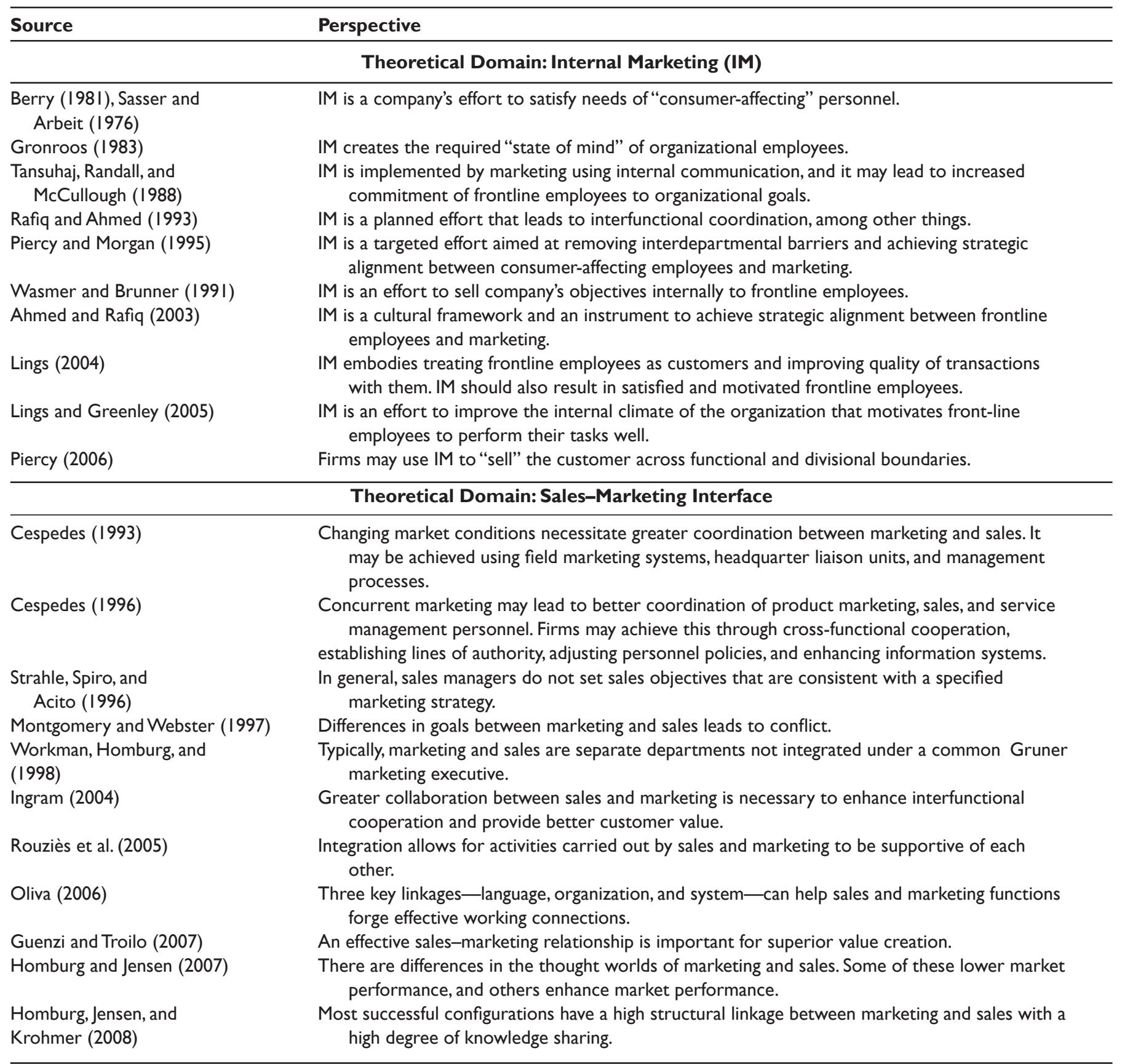

Ingram 2004). Further, initiatives such as sharing knowledge, maintaining open lines of communication, providing supportive leadership, bridging the thought world divide, and removing turf barriers may also forge stronger linkages between sales and marketing (Cespedes 1993; Dewsnap and Jobber 2000, 2002; Homburg and Jensen 2007; Homburg, Jensen, and Krohmer 2008; Ingram 2004; Oliva 2006; Rouziès et al. 2005). Overall, this stream of literature has pointed out the problem areas within this interface and focused on how to improve the dynamics between the two functions.

\section{Unresolved Issues and Research Questions}

The literature on internal marketing and the sales-marketing interface reveals important research gaps and unresolved issues. Specifically, internal marketing literature emphasizes that marketers must work toward getting salespeople's buy-in of their marketing strategies. It does not explicate, however, what buy-in means, what it takes to get sales buy-in, and what factors influence it. Similarly, the sales-marketing interface literature emphasizes the importance of the sales function supporting marketing's ini- 
tiatives to create superior customer value. However, it has not looked at the notion of buy-in, which may serve as one of the crucial preconditions for achieving an integrated, well-functioning interface. Taken together, explicating the nuances of sales buy-in will serve to bridge the gap between these two literature streams. Relatedly, in this paper, we address the following research questions:

\section{RQ1: What constitutes getting sales buy-in of mar- keting strategies within the sales-marketing in- terface - that is, what are the components of sales buy-in? \\ RQ2: What are the important organizational-level determinants of sales buy-in? \\ RQ3: What factors influence whether marketers achieve buy-in or not?}

\section{Method}

We used the grounded theory method to explore these questions. Grounded theory is a form of qualitative research methodology that enables researchers to obtain an in-depth understanding of a phenomenon and develop an explanation or theory that is "grounded" in data from participants who have experienced that phenomenon (Strauss and Corbin 1998). In this method, researchers collect data primarily through in-depth interviews using a sample of individuals chosen for their ability to provide an understanding of the phenomenon. This nonrandom sampling scheme is called theoretical sampling (Corbin and Strauss 2008, ch. 7). Its purpose is to obtain a deeper understanding of the issues and develop explanations and theory rather than provide generalizations. In grounded theory, researchers code the data to identify emergent categories and themes that provide an explanation for the phenomena under study. During the data collection process, the researcher conducts a set of interviews; analyzes the data; and based on the categories and themes that emerge, conducts additional interviews to get a deeper understanding of the themes, and identify new ones. This back-and-forth process of collecting data and comparing it to emerging categories constitutes the constant comparative method (Creswell 2007, p. 64). Researchers terminate the interviews when no additional insights emerge from the data - this is known as reaching theoretical saturation (Corbin and Strauss 2008, ch. 7). Sometimes theoretical saturation is reached after 20 to 30 interviews; at other times additional interviews need to be conducted (Creswell 2007, pp. 66-67).

There were two primary reasons we chose the grounded theory method. First, we needed a detailed understanding of the issues underlying the research questions; we could only obtain this through in-depth interviews of sales and marketing professionals. Second, the grounded theory method was necessary because existing theories did not adequately explain the complexity of the issues we were examining (Creswell 2007, pp. 39-41).

Our use of qualitative methodology is consistent with an emerging body of research that has used a qualitative research design to study firm strategies and other important organizational phenomena (e.g., Bechky 2006; Cross and Sproull 2004; Flint, Woodruff, and Gardial 2002; Noble and Mokwa 1999; Thompson, Rindfleisch, and Arsel 2006; Tuli, Kohli, and Bharadwaj 2007).

\section{Sample and Data Collection}

In accordance with the guidelines of the grounded theory method, we used a theoretical sampling scheme to select both sales and marketing professionals as our informants. This allowed us to maximize the variation among concepts and gather perspectives from both sides of the sales-marketing dyad. We collected data using the constant comparative method and terminated it upon reaching theoretical saturation after 49 interviews. During the data collection process, we approached 35 sales and 22 marketing professionals to request their participation in the study. Eight declined the interview request for confidentiality reasons, resulting in the final sample size of 49 . Our informants belonged to multiple companies, represented a broad spectrum in the sales and marketing organization hierarchy, and held a variety of job titles (see Table 2). All informants had been in their current job for at least three years and were qualified to answer our questions. The firms they represented varied in size and belonged to a diverse set of industries such as information technology (IT), telecom, engineering, pharmaceuticals, financial services, health care, engineering, and industrial products. Each firm had distinct sales and marketing functions (Kotler, Rackham, and Krishnaswamy 2006).

To maintain consistency in probing and depth of data collection, the lead author conducted all of the interviews. The interviews were discovery oriented (Deshpande 1983), lasting between 40 minutes and 110 minutes. The interviews took place at a location and time convenient to informants. Of the 49 interviews, we conducted 42 in person and 7 over the telephone. We recognize that compared with telephone interviews, in-person interviews may help the interviewer establish rapport with respondents, probe deeper, and gauge their reactions better (e.g., through reading body language and facial expressions), but the answers obtained through the two different methods do not differ much as far as quality is concerned (Emans 2004, p. 30 ). We confirmed this in our analysis and through member checks.

We began interviews in an exploratory manner so we could focus on each informant's phenomenological inter- 
Table 2. Sample Characteristics

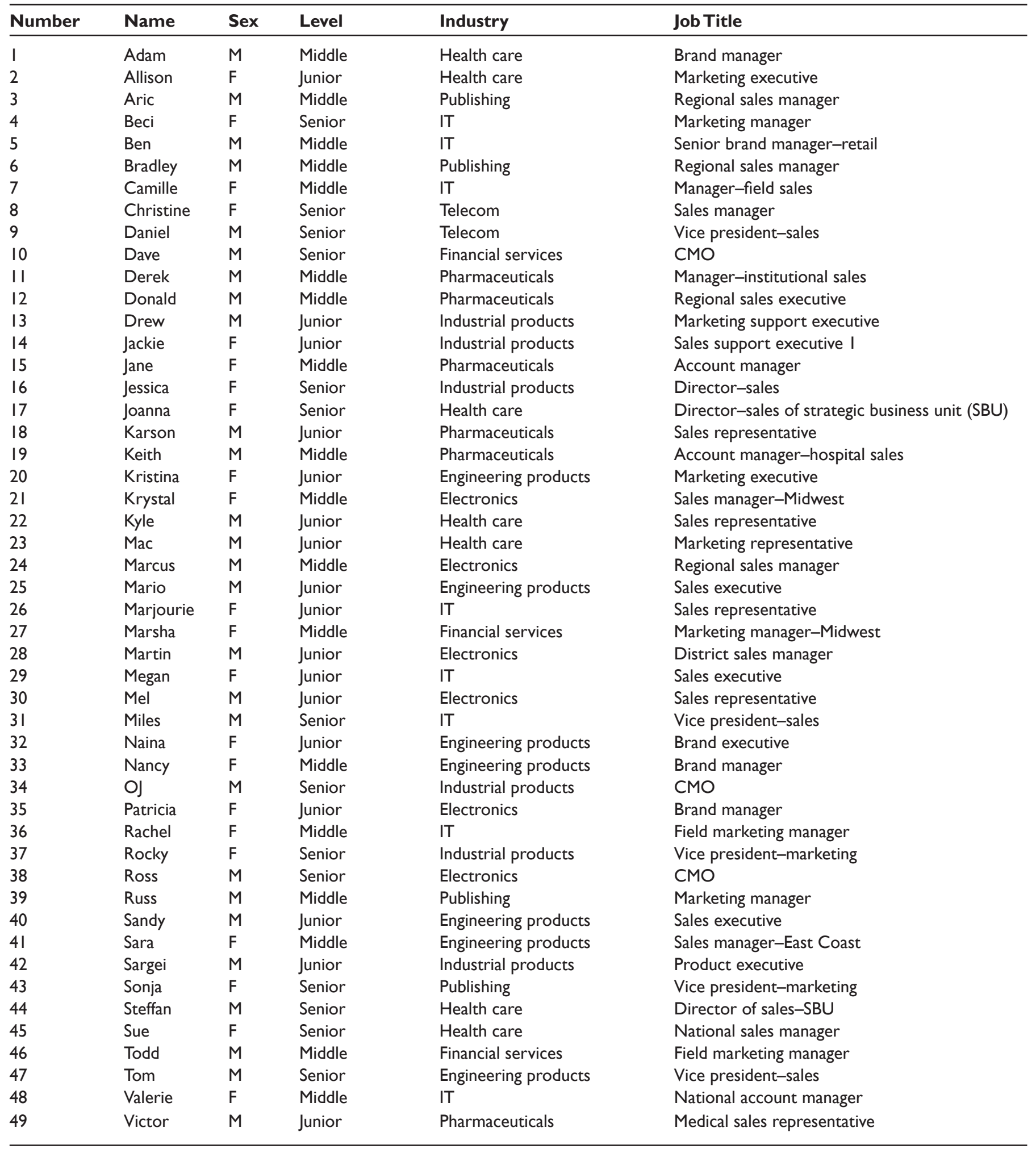

pretations of buy-in (Glaser and Strauss 1967). We used a structured set of questions for the interviews (see the Appendix). The sales- marketing interface was the unit of analysis, and we asked our informants to focus on "buy-in" at the functional level-that is, how the sales function, as a whole, bought into (or did not buy-into) specific market- 
ing strategies. By doing so, we steered clear of the phenomenon of individual buy-in (i.e., a specific sales professional buying into marketing's ideas, while at a functional level, the strategy not receiving a buy-in from the sales organization). Further, the context of discussion was a specific marketing initiative and how buy-in did or did not work for that initiative.

Following the interview protocol, we allowed informants to guide the flow and content of discussion, soliciting examples, clarifications, and related details as they spoke. We also maintained objectivity during the interviews to reduce interviewer-induced bias (McCracken 1988) and made efforts to clarify ambiguities. This provided informants an opportunity to correct anything we might have misunderstood or to elaborate on certain aspects as they deemed necessary. We tape-recorded all interviews and transcribed them verbatim. The 49 informant interviews represented more than 52 hours of audio recordings and approximately 525 pages worth of singlespaced transcripts. We used QSR International's NVivo software to manage all the data.

\section{Data Analysis}

Consistent with the constant comparative method, we analyzed the data on an ongoing basis. During this process, we first coded the information obtained from an interview using the process of open coding, in which we focused on and identified important in vivo codes-concepts based on the actual language used by the informants (Corbin and Strauss 2008, p. 65). We grouped the in vivo codes into higher-level concepts called first-order categories, based on some underlying similarities among them (Corbin and Strauss 2008, ch. 8). In the next step, we did axial coding, wherein we searched for relationships between and among the first-order categories (Corbin and Strauss 2008, ch. 9). This step helped us gather various concepts and assemble them into second-order themes. These themes helped us understand the emergent framework. We must note here that throughout the analysis, we avoided forcing emergent patterns into preconceived categories (Gummesson 2003).

Table 3 shows examples of our in vivo codes, first-order categories, and second-order themes. Table 4 provides examples of informant quotations and how we operationalized concepts related to each specific theme.

\section{Trustworthiness of Data}

In order to maintain data trustworthiness and ensure analytical rigor, we took a number of steps following Lincoln and Guba (1985) and Silverman and Marvasti (2008, pp. 257-270). First, we ensured that our data management process was comprehensive and rigorous. To do this, as noted earlier, we used the NVivo software as our qualitative data management program to maintain informant contact records, interview transcripts, field notes, and other related documents as they were collected. Second, we used the proportional reduction in loss method to assess the reliability of our coding scheme (Rust and Cooil 1994). We randomly selected 26 informant interviews, asked two independent judges to evaluate our coding, and calculated the proportional reduction in loss based on the judges' agreement or disagreement with each of our codes in these interviews. The two judges had prior experience with qualitative data analysis but were not involved in the study. The proportional reduction in loss for the current study was 0.76 , which is well above the 0.70 cut-off level recommended for exploratory research (Rust and Cooil 1994). This pointed to the appropriateness of our data analysis and interpretation. Third, the lead author asked an outside researcher experienced in qualitative methodology to conduct an audit of our empirical processes to ensure the dependability of our data. This outside researcher went through our field notes, interview protocols, coding schemes, and random samples of interview transcripts and documentation to assess whether the conclusions we reached were valid. This peerdebriefing process (Corley and Gioia 2004) provided us with an opportunity to solicit critical questions about our data collection and analysis procedures. It also allowed us to have our data scrutinized through other researchers' perspectives and ensure its trustworthiness. Last, we verified our interpretations and the accuracy of the findings using member checks (Creswell 2007, p. 208). Specifically, we shared our findings with 15 randomly selected study participants and asked them to offer their views on our interpretations of the data and the credibility of the findings. Of these 15 individuals, we interviewed four over the telephone. Our data interpretation and findings resonated well both with our peer reviewers and the informants used in member checks. This helped strengthen the validity of our results. Further, it confirmed that there was no significant difference between phone and in-person interview responses.

Because we had a diverse group of informants, we also assessed whether our informants' responses differed across informant-related variables such as gender, level within the organization, industry, experience, or job function. We did not find any major differences. Further, consistent with Bendapudi and Leone (2002) and Tuli, Kohli, and Bharadwaj (2007), we evaluated our insights and themes on three criteria: (1) applicability of idea beyond a specific industry, (2) how frequently informants mentioned an idea/theme, and (3) insightfulness. Even though many issues and insights emerged from our data, in the next section, we discuss only those that provide new insights within the context and are not idiosyncratic to any specific industry. 
Table 3. In Vivo Codes, First-Order Categories, and Second-Order Themes for Buy-In

\begin{tabular}{|c|c|c|}
\hline In Vivo Codes & First-Order Categories & Second-Order Themes \\
\hline Fact-based discussion & Balanced & \\
\hline Unbiased perspective & Neutrality & \\
\hline \multicolumn{3}{|l|}{ Explain rationale } \\
\hline \multicolumn{3}{|l|}{ Being rational } \\
\hline Our world is different & Openness & Sensitivity and responsiveness to reality \\
\hline $\begin{array}{l}\text { Allow us to ask questions; encourage } \\
\text { questions }\end{array}$ & $\begin{array}{l}\text { Diversity } \\
\text { Sensitivity }\end{array}$ & \\
\hline Our contribution & Participation & Involvement in strategy creation \\
\hline Assess feasibility of strategies & Give and take & \\
\hline \multicolumn{3}{|l|}{ Platforms-advisory boards } \\
\hline \multicolumn{3}{|l|}{ Come into our accounts with us } \\
\hline \multicolumn{3}{|l|}{ We will test your ideas } \\
\hline \multicolumn{3}{|l|}{ Take your constructs out to the field } \\
\hline \multicolumn{3}{|l|}{ Negotiation with field force } \\
\hline \multicolumn{3}{|l|}{ We have a say in the process } \\
\hline Provide consistent support & Backing & Positioning for success \\
\hline Utility of what is being sent to us & Prepare & \\
\hline
\end{tabular}

\section{FINDINGS}

RQ1: What Constitutes Getting Sales Buy-In of Marketing Strategies Within the Sales-Marketing Interface?

At the outset, we wish to emphasize that the concept of buyin was important and pertinent to our informants. Although the academic literature has not specifically addressed this phenomenon, practitioners found the notion of buy-in crucial when it comes to strategy creation and execution across the sales-marketing interface. Daniel and OJ's quotations are very pertinent:

The key to success for launching many of these strategies is having our salespeople buy into it and getting their feedback. [Daniel, Vice President of Sales]

Your strategy will go nowhere unless you get your field force's buy-in. That is the first major task. [OJ, Chief Marketing Officer; CMO]

Sara had a similar opinion. When commenting on the importance of sales buy-in, she mentioned that it was comparatively easy to put together marketing collateral. In her opinion, getting sales buy-in was the most crucial and difficult part of strategy execution:

It is easy to put together a communication package and different sales literature ... the media and all that stuff. It is easy to get all that. The real issue is whether your sales force buys into it. ... Are your reps willing, prepared, enthusiastic, trained, and excited about executing the strategy. [Sara, Sales Manager]

Sales personnel are boundary spanners and play a crucial role in ensuring that firms implement their strategies appropriately (Singh 1998). Consistent with Sara's opinion above, Tom highlights how having the best message or the best product may not be of much value unless the sales personnel have bought into the story and made it their own:

I think buy-in comes from more than just incenting them [salespeople] with a lot of commission to make money on it. 


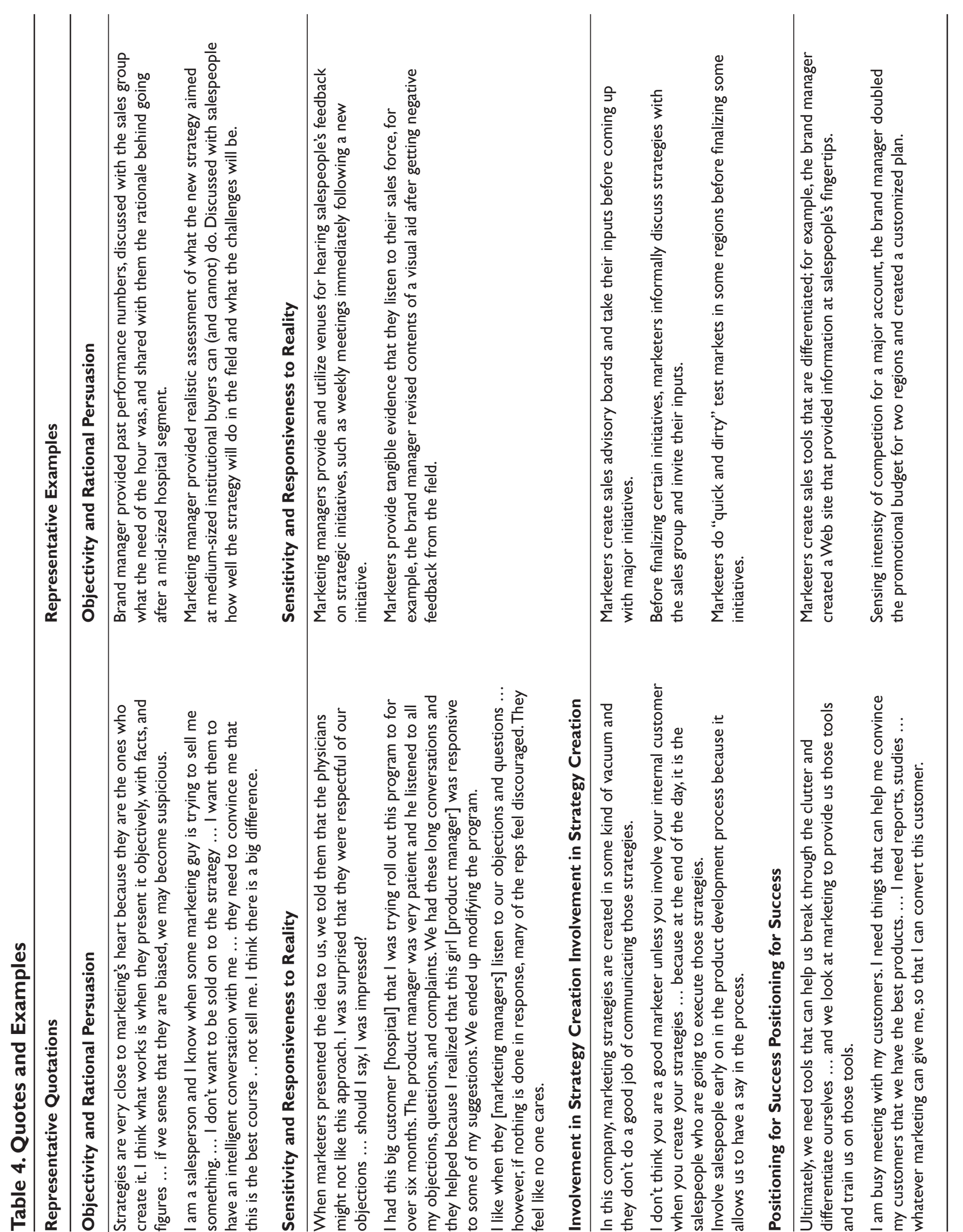


At the end of the day, they still have to believe the story they are telling their customers. If they have not bought into the story and made it their own, then strategically you can have the best message, the best product, the best everything ... and still you might not sell anything because they do not believe what is being sold. [Tom, Vice President of Sales]

It is noteworthy that Tom mentions getting a sales buyin requires more than "incenting" (offering monetary incentives) salespeople. This insight advances our understanding of the sales-marketing interface that, at present, highlights the importance of compensation in driving salesperson's activities (Matthyssens and Johnston 2006; Menon, Jaworski, and Kohli 1996). Further, it is consistent with Ahmed and Rafiq (2003), who argue that achieving strategic alignment between marketers and frontline employees is important so that salespeople are internally motivated to serve customers.

Our data helped unravel the complex nature of sales buyin - an area not discussed specifically in the marketing literature. The data indicate that getting sales buy-in consists of four key components: (1) objectivity and rational persuasion, (2) sensitivity and responsiveness to reality, (3) involvement in strategy creation, and (4) positioning for success.

\section{Objectivity and Rational Persuasion}

Our informants mentioned that getting sales buy-in is contingent upon marketing being "objective and fact based" in their discussions about upcoming marketing strategies with salespeople. Our data indicated that if sales personnel perceived that marketing managers were trying to push their own agenda under the guise of a strategy, it was likely to turn them off and negatively affect buy-in. On the contrary, when marketers (1) operated in a fact-based environment; (2) shared with salespeople the necessary background data that they used to create strategies; and (3) presented an unbiased, rational assessment of market situations (e.g., nature of competition, growth prospects), sales personnel could see the broader picture and were receptive of their ideas.

Miles's quotation below brings out how maintaining objectivity and a rational tone in discussing strategies helped his marketing colleagues. The notions of being objective, rational, and fact-based are salient here:

Like ... for this product, we [marketing and sales leadership] came up with a new plan and we went to my sales group and told them, "look, this is what has driven our growth and this is where the future is ... and this is how our new product fits in the big scheme of things." We made it clear that it would not be an easy sale, but also highlighted the benefits that they would get ... as simple as your revenue will grow by 15 percent in the next two years, and you would be able to get three new accounts with this new product. So, we asked them to do the math and they understood for themselves that it was pretty attractive for them. [Miles, Vice President of Sales]
Marsha indicated how it helped getting sales buy-in when marketers helped salespeople see the bigger picture and explained to them the rationale behind a certain strategy:

One of the things we struggled with initially was that the salespeople did not understand why we were targeting midsize businesses. They were not seeing it as a big opportunity. When we shared with them findings of our market research and showed them why we thought it was big, they seemed to agree. I think what worked was that they understood the "why" behind our strategy. [Marsha, Marketing Manager]

Many of our informants noted that even though salespeople did not create strategies, it was important that marketers appreciated salespeople's ability to process strategic information. Relatedly, salespeople expected marketers to have intelligent and convincing conversations about the foundation of a particular strategy. Adam explained:

It is a mistake to treat your salespeople as pure executors, who will follow your directives blindly. It turns them off if you are not willing to discuss with them the pros and cons of your strategy, or why this strategy is appropriate. I have found that they are more open to accepting my strategies when I get them involved in discussing those strategies instead of just sending them memos ... simple memos do not work. [Adam, Brand Manager]

The last facet of this theme was that salespeople did not like to see marketers sell their strategies to the sales force. Our sales informants felt that it was insulting if marketers tried to sell them on marketing plans. Instead, they preferred that marketers treat them as intelligent individuals capable of assessing the merits and demerits of a strategy. This insight is consistent with a stream of internal marketing literature that highlights the importance of enhancing the quality of interaction with internal customers as an important determinant of successful internal marketing (Frost and Kumar 2000). However, it contrasts the extant trade literature on sales-marketing interface (e.g., Lorge 1999) as well as the broader academic literature on internal marketing (Gronroos 1983) that advises marketers to treat frontline employees as internal customers and sell them their ideas.

Keith, one of our informants from sales, was vociferous about this aspect:

To me, it is insulting to sell [your plans] to a salesperson. When [marketing] people try to sell to me, it is frustrating, because I know exactly what they are doing. I would much rather they approach me with a straightforward discussion and respect my intelligence versus trying to persuade me. I have had people, who try to sell to me, and they use our sales tactics and I always know where they are going next. I let them go through it and kind of smile, but it is not going to persuade me. What will persuade me is being straightforward, being sincere and simply talking about it. [Keith, Account Manager] 
Sensitivity and Responsiveness to Reality

Sensitivity and responsiveness emerged as the second component of sales buy-in. We found that when marketing personnel appreciated their differing worldviews from salespeople (Homburg and Jensen 2007; Panigyrakis and Veloutsou 1999; Workman, Homburg, and Gruner 1998), exhibited sensitivity toward salespeople's field experiences, listened to their questions and ideas, and responded appropriately, salespeople in return, were more open to what the marketers were telling them.

Daniel discussed what it meant to be sensitive to field realities. As he notes, if marketers understand the unique challenges some sales regions pose, and take the initiative to customize marketing programs for those regions, it signals to the sales organization that marketers are sensitive to what is going on in certain territories. It also suggests that they are actively engaged and thinking about the sales process. This motivates frontline employees, and they in turn become more responsive to marketers' ideas and suggestions:

They [marketing] have focused on certain problem territories on the West Coast that are not doing very well and they have tried to customize quarter two strategy for those three territories. Salespeople know that it is difficult to customize strategies for each region in the country ... that will be crazy. However, if you do it in a few territories, learn from those territories, that helps a lot. More than anything else, it shows to the sales force that you are trying to be sensitive and responsive to the field realities. ... You understand that one-size-fits-all approach may not work everywhere. ... Once they see that, they are more responsive to what you tell them to do. [Daniel, Vice President of Sales]

Salespeople, owing to their constant interaction with final customers, have valid insights into the potential success of a new strategy. Another way in which marketers could exhibit their sensitivity toward salespeople's perspectives would be by encouraging questions from the sales force while presenting a new strategy. Such a dialog would allow them to understand the sales organization's capabilities and potential obstacles to implementing the strategy (Reynoso and Moores 1996). As Ross, a CMO, indicated:

I always advise my marketing managers to invite questions and comments from the field. They are out there meeting customers ... and no marketing strategy will succeed unless it answers all the issues and questions they face out there. We want to know what problems they foresee in implementing our plans ... customer issues, channel issues. ... We invite questions. ... Plus, seeking out questions goes a long way in letting the field force know that we are here to listen to their perspectives and issues. [Ross, $\mathrm{CMO}]$

Our data showed that it was important for marketers to not only encourage questions from the sales force but also respond to their ideas and concerns. Our informants noted that marketers could exhibit their responsiveness verbally (e.g., reacting to salespeople's ideas and concerns) or in the form of a tangible response (e.g., modifying certain plans based on sales feedback).

\section{Involvement in Strategy Creation}

Sale's involvement in the strategy creation process emerged as the third theme of sales buy-in. Both sales and marketing personnel felt that when salespeople were part of the strategy creation process, they felt more committed to it and, hence, bought into it. As Joanna, the Director of Sales with a healthcare company, indicated:

When you are in the initial stages of discussion about your strategy and its execution, you have to get the buy-in at that very time and negotiate many things with the sales force so that they are completely on board from the start and you do not have many problems later. [Joanna, Director of Sales]

As a part of involvement, marketers need to engage sales personnel in dialog so they are abreast of how marketers develop strategy and are able to offer insights. As Beci noted:

Many of our strategies failed in 2007 because there was no dialog between sales and marketing. ... One of the first things I did when I took over was that I initiated a constant dialog between sales and marketing. I invited sales leadership and middle managers to offer suggestions on our plans. ... It made a huge difference. ... They became stakeholders in the process and it helped us greatly as we moved through the implementation stage. [Beci, Marketing Manager]

While dialog is crucial, our data suggested that marketing's openness to negotiation during this process was equally important in ensuring that salespeople remained involved. Our informants were mindful that marketing and sales do not always share similar orientations or objectives (e.g., short term versus long term, market share versus profitability) (Cespedes 1996; Strahle, Spiro, and Acito 1996). Hence, when such differences came to the forefront, it was important that marketers were open to negotiation with the sales force on how the strategy could be adapted. When negotiations were fair, the sales force felt that marketers valued their involvement, and it helped get their support for marketing's initiatives. Russ noted:

It is important to be open to new ideas from the field during the initial stages of strategy creation. You do not have to agree with every objection and suggestion from the field ... but you have to be a fair negotiator. ... I go into these discussions knowing that they bring a different perspective to the table about many strategic and tactical issues ... and I have to be fair to them and appreciate their points of views. It creates a great impression and helps them see that they are a part of this process [Russ, Marketing Manager] 
Our informants highlighted that marketers could use platforms such as sales advisory boards or cross-functional teams to involve salespeople in the strategic initiatives. Such platforms allow marketers to seek salespeople's feedback on issues such as feasibility of implementing a particular strategy, merits of specific strategies, and obstacles they foresaw at an early stage (Reynoso and Moores 1996). Camille's experience below clearly brings forth this point. She attributes the success of a particular marketing initiative to marketing's proactiveness to involve the sales force early in the process. As she notes, it helped iron out any glitches early:

Where they [marketing] did a good job was last year. When they had an idea for a new product, they came to sales right away and said, this is what they were thinking about. They also came with us out in the field, went into our accounts and got feedback ... so we had both marketing and sales together listening to what the existing customers said. Afterwards, they also formed sales advisory boards so that they would have data about prospects and existing customers. ... That program was immensely successful because we were all excited about it and we had ironed out the glitches initially. [Camille, Manager-Field Sales]

It is not always possible for marketers to involve salespeople in strategy creation. In such cases, marketers need to test market their ideas before finalizing a formal marketing plan. Todd shared his experience in this regard:

Nothing that comes from HQ [headquarters] to our region is implemented unless we test market it on a smaller scale. It serves multiple purposes. First, we can tweak the strategy a little bit based on the response we get during the test market. More importantly, it gives salespeople a chance to comment on the strategy and let their voices be heard. They make suggestions and improvements ... it gives them a sense of involvement, which is so crucial moving forward with the strategy. [Todd, Field Marketing Manager]

Our sales informants were cognizant of the fact that at times, marketing may not be able to incorporate their feedback and suggestions. In such situations, they wanted to hear back from marketing about how their feedback was processed, and why they did not incorporate it. They did not want marketers to leave them wondering about what happened to the feedback. This is consistent with a perspective on internal marketing that highlights the importance of feedback mechanisms in achieving successful internal marketing (e.g., Hurley 1998). As Jackie indicated:

They [marketing] listened and showed [evidence] that they listened. So we knew. When they disagreed with us, they would say ... "we heard you talk about price reduction ... but we are not going to do it right now because it will affect profitability." ... And they showed us some numbers ... so that is the kind of feedback we expect. It did not matter then that they did not accept our feedback ... they were at least open about it and told us why. [Jackie, Sales Support Executive]

\section{Positioning for Success}

The final theme that emerged from our data was that the sales force was looking at marketers to "position them for success." This theme is important for two reasons. First, in spite of the changing nature of the sales organization (Piercy 2006), scholars suggest that marketing still acts as an important support function for the field force (Cespedes 1996; Matthyssens and Johnston 2006). Our theme indicates that the sales organization is looking for the kind of support from marketing that would give them competitive advantage in the field. Second, this theme indicates that even though sales force members want marketers to take their feedback and involve them in the strategy creation process, achieving sales objectives remains an important focus for them. This insight confirms some of the evidence in the extant literature which points out that at the end of the day, sales organization members are results driven (Carpenter 1992; Lorge 1999). Not surprisingly, they want marketing to support them in ways that will help them succeed in the marketplace:

If we feel that marketing is doing stuff and producing material that is not benefiting us in the field in any way, or as a salesperson, if I start questioning the value of what is being sent to me, then I start focusing on other things, and completely disregard marketing strategies because it is not relevant to me. [Bradley, Regional Sales Manager]

Victor highlighted another important facet of this theme:

A salesperson's life is busy. ... We work 12 hours a day, and if you do not bring a lot of value to us, we are not going to spend a lot of time on you because we don't have that kind of time. So the perceived value is big. ... As a marketer, you need to come across as someone who can help us. Our last product launch was great because all through the process, we remember marketing managers saying ... "how can we help you make your job better and easier? How can we help you be successful?" Wow, bring it on. Guess what happens in return ... we also want to make sure that your products and programs are successful, right? [Victor, Sales Representative]

As he mentions, when salespeople see marketing managers making efforts to ensure that they receive appropriate support in the field, and add value to their work so that they are successful, it improves the internal climate within the sales-marketing interface, and makes them feel excited about their work. They reciprocate marketing's efforts with their own commitment to marketing initiatives. This induces a positive cycle in that the salespeople feel responsible and driven to ensure that plans and programs proposed by marketing are successful. 
In summary, our data indicate that the notion of buyin consists of four major components: (1) objectivity and rational persuasion, (2) sensitivity and responsiveness to reality, (3) involvement in strategy creation, and (4) positioning for success. Our discussion above brings forth how each of these components, when handled appropriately within the organization, helps salespeople internalize their beliefs about the appropriateness and merit of a marketing strategy and feel excited about executing it wholeheartedly in the field.

\section{RQ2: What Are the Important Organizational-Level De- terminants of Sales Buy-In?}

Three organizational-level factors relating to structure, culture, and relationship issues emerged as important determinants of sales buy-in. We explore these factors here.

\section{Eliminating Interfunctional Walls}

Our data indicated that eliminating "walls" that separated different functions and created "silos" within organizations could facilitate sales buy-in. Many of our informants mentioned that their companies had functional silos that negatively affected the process of rationale sharing between sales and marketing. They further noted that these barriers hampered the process of asking questions and giving feedback. The silos also prevented salespeople from being involved in the process of strategy making. Our sales informants mentioned that when firms had distinct silos, they did not feel comfortable dealing with their marketing counterparts, which took away the possibility of fair negotiations with them.

Jessica, one of our informants, shared her experience. As she notes, her company has rigid silos that restrict the free flow of information. She suggests that marketing and sales have to make efforts together to tear down the walls and make sure that the two functions freely exchange market-related information. As she points out, when the sales function is able to understand what marketing is thinking about, they get a much clearer picture of the rationale behind the strategies, and it helps them come on board:

Together you have to focus on eliminating those walls between functions if you want us to be on board with your strategies. Companies have islands of information. In our company, if you take the smoke pipes and gather all of the smoke from each of them, we would be a much better company. If we bring the information back to marketing, they are successful only when they listen, make their interpretations known to us, and take action on what we tell them is happening in the marketplace. It helps if there are open lines of communication because we can know what they are thinking. [Jessica, Director of Sales]

\section{Bridging the Cultural Divide}

Scholars studying the sales-marketing interface emphasize cultural distinction as one of the important differentiating factors between the two functions (Beverland, Steel, and Dapiran 2006; Rackham and DeVincentis 1999). Consistent with the extant literature, our informants referred to a cultural divide between sales and marketing in terms of differences in short- versus long-term orientation, strategic versus tactical focus, or focus on philosophy versus field reality. Our informants mentioned that such a divide between sales and marketing functions was inevitable. They felt, however, that it was important for both sales and marketing personnel to take the initiative and make proactive efforts to bridge that divide. When salespeople see marketing trying to create a strategy that accommodates the goals of both functions, it goes a long way in telling them that marketing is trying to make efforts to bridge the cultural divide:

Salespeople are always going to be short-term and narrowly focused, if you will. ... There is no denying ... that cultural divide is always gonna exist. I think what worked with this new product management group is that they made conscious efforts to bridge that gap. ... Not that they had a winning formula ... they stumbled many times ... but the fact that marketing was making efforts was important to us. They were looping in our short-term objectives with their long-term plans and programs. I think it is incredibly important to build those bridges. ... You gotta make things work. ... They may not work if left by themselves. [Mel, Sales Representative]

Bridging the cultural divide is not just a one-way process; salespeople have to make an effort to bridge this gap, too. When marketing personnel perceive that the sales function is making an effort to reduce the gap, they are more open to listening and responding to objections, and negotiating with sales group. This comes across in Naina's quotation:

The effort to bridge this cultural gap has to come from both sides. During our last quarter strategy discussion, it was very encouraging to see our field force being so supportive. They did not like everything I presented ... they thought that some of my ideas were esoteric ... however, clearly, they were not out there to shoot down my plan. ... They were voicing concerns and were very constructive in their feedback. That was encouraging to me ... it made me more open to negotiating with them and tweaking some of my ideas so that it could fit in their workday. [Naina, Brand Executive]

\section{Relationships}

Our data suggest that the interfunctional relationship between sales and marketing is another factor that determines sales buy-in. Both sales and marketing informants characterized interfunctional relationships in terms of in- 
terpersonal rapport between sales and marketing individuals. Our data also revealed that such relationships formed across different levels within the marketing and sales hierarchy. We observed cases where district managers or sales representatives shared a good personal rapport with marketing managers. We also saw instances where the vice presidents of sales had a friendly relationship with many brand managers.

What helps build such close interpersonal relationships? Our data suggested that if each function appreciated the work done by the other, it reduced the feeling of alienation and animosity, and helped build a mutual respect. Such respect then helped forge better working connections and stronger relationships between the two functions. When the interface partners lacked mutual respect, it posed serious problems in getting sales buy-in. Krystal noted:

If you do not care about our world and respect what we do, we are not going to give you the appropriate respect. It is like teamwork ... and mutual respect is so essential for a team to function. As a marketer, if you think that you are the only driving force behind a strategy, you are completely wrong ... because unless my salespeople work their butt off, your plan is not going to have a chance. What I have seen in this company, which is very dysfunctional, is that marketers really do not respect the efforts that my people put in. It is disappointing and disheartening. It alienates the sales force and they, in turn, do not care about you or your programs. [Krystal, Sales Manager]

\section{RQ3: What Factors Influence Whether Marketers Achieve Buy-In or Not?}

Our informants discussed a wide range of issues related to getting buy-in, but two factors-organizational hierarchy and strategy absorption time-kept cropping up repeatedly in our discussions as contextual conditions. In particular, our informants suggested that merely addressing the issues such as eliminating interfunctional silos, bridging the cultural divide, or establishing close interpersonal relationships within this interface may not necessarily lead to sales buy-in. There are some boundary conditions that, when met, may facilitate sales buy-in. They also emphasized that ignoring these factors may pose challenges for marketers in getting sales buy-in, even when they have attended to the variables such as interfunctional silos or bridging the cultural divide. In this section, we highlight how these two conditions-hierarchy and strategy absorption time-determine the success or failure of achieving sales buy-in.

\section{Hierarchy}

Sales and marketing organizations consist of hierarchies, where people at different levels have different responsibilities. Nonetheless, each member in this hierarchy plays a specific role in implementing marketing strategies. Our informants represented a wide spectrum of sales and marketing hierarchies. During our discussions, each of them emphasized how important it was to obtain buy-in at multiple levels within the sales organization. This shed light on an important insight-if marketing strategies had any chance of success, it was imperative for marketers to get buy-in from all levels within the sales hierarchy.

Martin, a district manager, who led a team of six sales representatives, mentioned how important it was for marketers to get a buy-in from mid-level managers like him. In his quotation below, he refers to one of their failed initiatives. It clearly brings forth the fact that mid-level managers may send signals to their sales representatives about how excited they are about a particular strategy. If salespeople perceive that their leader is not excited, it is likely that the team may not give that strategy adequate attention:

Implementation can fail on a number of different levels. Last quarter, one of our programs for our top-ten IT clients failed in my district, because myself, as a district manager, I did not feel too excited about the program. ... Obviously, I did not give it the proper attention it deserved and that kind of cascaded down. ... When my reps saw that I didn't support it ... they didn't either.

[Martin, District Manager]

Our data indicated the importance of getting buy-in from the bottom of the sales hierarchy as well. Patricia explained how one of her plans for business customers failed because the salespeople did not see any merit in her plan and did not embrace it completely:

As far as I can tell, it was a very strong strategy. We had market data to back up everything we had planned and the sales leadership was convinced that this would increase our market share. Unfortunately, our salespeople did not see it that way. They did not like the idea and did not see any merit in our approach. The initiative bombed at the field level in spite of having a strong leadership support. [Patricia, Brand Manager]

Last, when the sales leadership did not believe in the merits of a strategy, it created a huge hurdle. Leadership's support can determine whether marketing initiatives succeed or fail (Kohli and Jaworski 1990). Our findings were consistent with this assertion. As the quotation below highlights, Sara takes pride in the fact that marketing leadership in her company consults with her before rolling out their plans. As she clearly mentions, her blessings are vital if the plan is to succeed - a clear indication of the criticality of getting buy-in from sales leadership:

They [marketers] start with the sales director (that is I) and they give me a feel for what they are thinking. They explain in detail the strategy and their programs. Then I weigh in and talk about, what is manageable. ... 
I also tell them what is just too much ... also, if there are things that my [sales]people cannot handle at this point, I make that clear, too. ... I tell them to spread certain plans over a longer time period ... and so we have lots of discussions about it. They know they need my blessings if they want my guys to execute their plans [laughs]. [Sara, Sales Manager]

\section{Strategy Absorption Time}

The second contextual factor our informants mentioned frequently was time to absorb the new strategies. Specifically, they emphasized that if marketers are interested in getting sales buy-in, they needed to give them an ample amount of time to ponder over their ideas and soak them up fully before asking for feedback, or expecting them to commit their resources to those ideas.

Giving the sales personnel adequate time to absorb key strategic ideas was critical for two reasons. First, our sales informants mentioned that their lives were busy. If they were to comprehend how different components of a strategy fit together and how the entire implementation process would unfold, it would require them to carve out time from their busy schedules, reflect upon the various components of the strategy, and internalize how the strategy might work. Second, they mentioned that most salespeople liked to test marketers' ideas with their customers and interpret for themselves the feedback they received from the customers. It allowed them to internalize the strategic and tactical aspects of the proposed strategy. Taken together, they expected marketers to allow them adequate time to absorb all the information and process it carefully, if they wanted them to be on board.

What came across from our data was that if marketers pushed the sales organization to adopt a strategic initiative quickly, the sales force resisted such efforts and it negatively affected sales buy-in. Martin, a district manager with an electronics company, used the following analogy to explain what he meant:

We will park the idea and we will come back to it. We will talk with our customers about it and see what they say. I have explained to them [marketing], we have to roll before we can crawl, and we have to crawl before we can walk. As much as I would like to go to straight walking, I am not at that point yet ... so it is going to take time. [Martin, District Manager]

Nancy, a brand manager with a major engineering firm voiced a similar opinion:

You think salespeople are go-getters and they love speed of action, right? Not really. ... When it comes to digesting new ideas ... the golden lesson I have learned over the years is that if you want your idea to move forward, just introduce it to the sales force and let them think about it for a while ... then get their feedback. ... Never push them into doing something before they have had a chance to understand why they are asked to do something. ... If not, you will get a push back and they will resist your idea even without thinking through it. [Nancy, Brand Manager]

\section{Discussion}

Even though the importance of getting sales buy-in of marketing strategies is widely recognized, no one has studied what it actually entails. In this paper, we show that getting sales buy-in is a multifaceted phenomenon that consists of four key elements. Further, we identify three intraorganizational determinants of sales buy-in and highlight how organizational hierarchy and time for salespeople to absorb the key strategic ideas serve as the boundary conditions that affect this phenomenon. Table 5 offers a snapshot view of the major findings of this study. In this section, we highlight how findings of this study contribute to the extant knowledge in this area.

\section{Theoretical Contributions}

Trade and academic literatures on internal marketing, sales- marketing interface, and marketing strategy implementation, either directly or indirectly, allude to the importance of getting buy-in for marketing strategies from the sales force. Specifi- cally, scholars emphasize that internal marketing initiatives are necessary for enhancing frontline employees' commitment to firm's strategic goals, and for achieving a strategic alignment between salespeople and marketers (Rafiq and Ahmed 2000). Further, the literature on the sales-marketing interface (Homburg, Jensen, and Krohmer 2008; Kotler, Rackham, and Krishnaswamy 2006; Rouziès et al. 2005) and marketing strategy implementation (Ruekert and Walker 1987; Varadarajan, Jayachandran, and White 2001) indicate that it is important for both salespeople and marketers to be integratedthat is, be supportive of each other's activities to offer superior customer value.

Even though all of these literature streams implicitly assume the presence of sales buy-in, no one has discussed what it takes to get the buy-in. With this backdrop, the first contribution of our study is in explicating the various components and nuances of buy-in. The notion of buy-in also serves to bridge the literature streams of internal marketing and the sales- marketing interface. Obtaining buy-in can be an important outcome of internal marketing initiatives and is necessary for successfully implementing marketing strategies and developing sales-marketing integration.

While buy-in plays a bridging role, our findings also provide insights that are contrary to what we find in these literature streams. Specifically, internal marketing literature emphasizes that marketers treat customer-affecting employees as internal customers and use various communication methods to market their ideas to them (Piercy 


\section{Table 5. Summary of Findings}

\section{RQI:What Constitutes Getting Sales Buy-In of Marketing Strategies Within the Sales-Marketing Interface?}

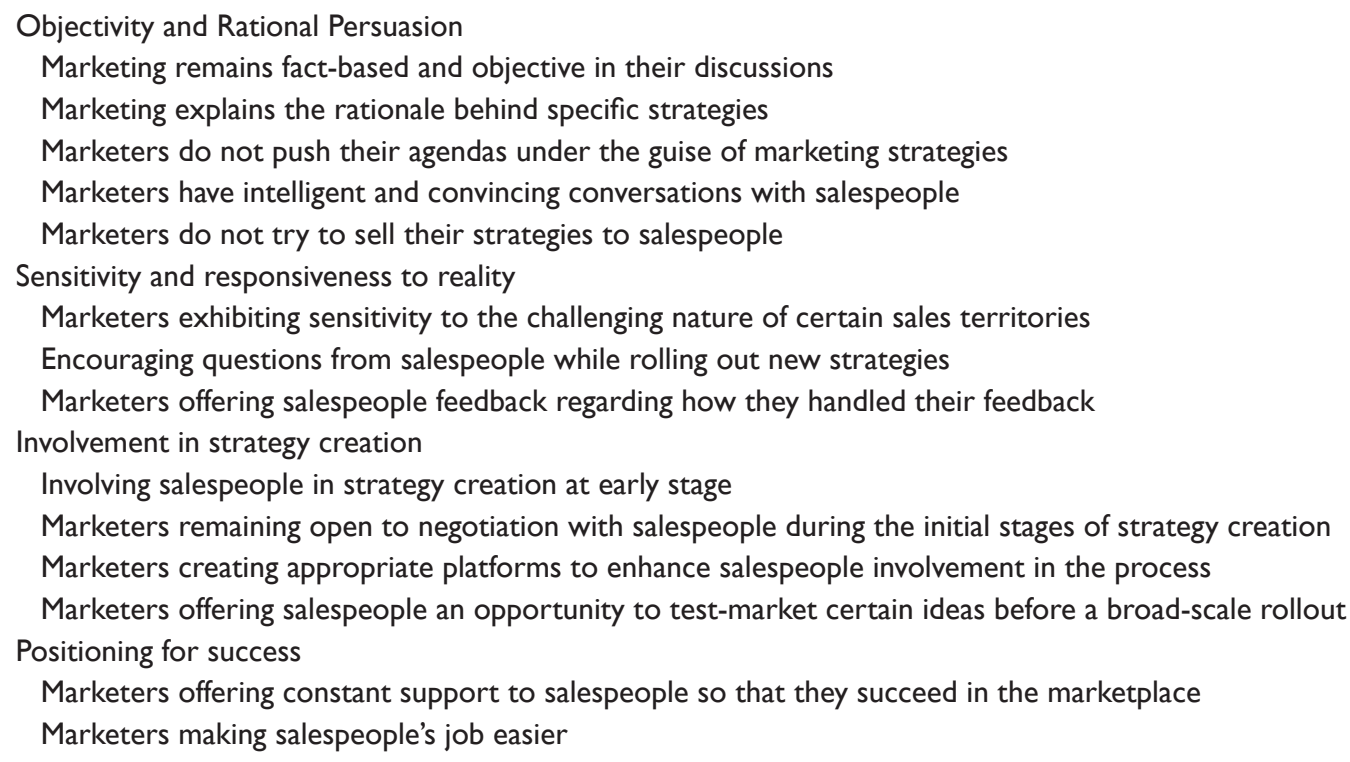

\section{RQ2:What Are the Important Organizational-Level Determinants of Sales Buy-In?}

Eliminating interfunctional walls

Marketers being proactive in eliminating silos and encouraging free flow of information

Bridging the cultural divide

Both marketing and sales making every effort to bridge the cultural gaps between them

Relationships

Establishing close interpersonal relationships between sales and marketing personnel across different levels within marketing and sales hierarchy

\section{RQ3:What Factors Influence Whether Marketers Achieve Buy-In or Not?}

\section{Hierarchy}

Marketers ensuring that each level within the sales hierarchy has bought into the strategy

Strategy absorption time

Marketers allowing salespeople adequate time to ponder over strategies and not rushing in

2006; Wasmer and Brunner 1991). Our explication of the theme "objectivity and rational persuasion," however, indicates that contrary to extant belief, marketers' efforts to sell strategies to their sales counterparts may prove to be counterproductive. Our data suggest that marketers may achieve better success if they engage the sales personnel in objective, fact-based, intelligent conversations and do not pitch their strategies to them. Similarly, contrary to extant sales-marketing interface literature that highlights how compensation may play an important role in driving salespeople's behavior (Dewsnap and Jobber 2000; Donath 1999; Rouziès et al. 2005), our findings indicate that monetary rewards alone may not ensure sales buy-in. For marketers to obtain buy-in, salespeople have to be involved in strategy creation and have to believe in the merit of the strategy. The second contribution of our study thus lies in bringing forth insights that are contrary to what we find in extant literature, and offering new perspectives on these issues.

Our third contribution lies in showing that several organizational-level variables central to literature in strategy and the sales-marketing interface are also relevant to understanding the buy-in concept. Specifically, the interface literature has shown the importance of organizational structure, culture, and processes (e.g., Beverland, Steel, and Dapiran 2006; Cespedes 1993; Guenzi and Troilo 2007; Ingram 2004; LeMeuneir-FitzHugh and Piercy 2007; Oliva 2006). Relatedly, research in marketing strategy (e.g., Kirca, Jayachandran, and Bearden 2005) highlights how interfunctional dynamics or organizational culture may affect firm's various strategic outcomes. Our findings related to breaking silos, bridging the cultural divide, and building strong interfunctional relationships show that these stra- 
tegic variables are also applicable to obtaining sales buyin. Further, our findings bring out additional facets of these variables that are important for buy-in.

Extant strategy literature alludes to the importance of the temporal and hierarchical elements in the firm's strategic initiatives (Srivastava, Shervani, and Fahey 1999; Workman, Homburg, and Gruner 1998). However, nowhere do we find an explicit discussion of how these elements may affect the sales-marketing interface-a place where strategy creation and execution take place. The fourth contribution of our paper therefore lies in identifying the role of these two variables as boundary conditions in determining whether sales buy-in happens or not.

The extant sales-marketing interface literature is predominantly conceptual. Owing to the strategic importance of this interface within market-driven organizations (Day 1994), scholars have highlighted a greater need for empirical work in the area (e.g., Rouziès et al. 2005). Our study responds to this call and empirically investigates this area using a qualitative research design. This in itself constitutes an important contribution to the sales literature.

\section{Managerial Implications}

Current evidence from the business world suggests that many marketing strategies fail because the sales force does not accept marketers' initiatives wholeheartedly (Aberdeen Group 2002). Extant trade and academic literature indicates that such failures may be a function of sales and marketing not being on the same "wavelength" or they being "out of sync" with one another (Cespedes 1996; Donath 1999; Kotler, Rackham, and Kirshnaswamy 2006). Findings of our study offer the first glimpse to managers in this regard with respect to what sales buy-in entails and how marketers may achieve it. Specifically, managers will understand from our findings that getting sales buy-in is a complex process consisting of four key components. If they want to get buy-in from sales, they need to work on many different fronts simultaneously; there is no magic bullet to achieve buy-in.

Our findings suggest to managers that while attempting to get sales buy-in, it is advisable to be objective and present rational arguments to their sales teams. Our findings further advise marketing managers against pushing their agenda or treating salespeople as internal customers who must be sold on an idea. Instead, managers may use various forums such as monthly meetings or conference calls and involve salespeople in engaging conversations about the strategies. Our findings suggest that salespeople prefer discussion versus directives. They respond well to a conversational approach in strategy discussion, rather than someone telling them what they should do. Marketers must keep this in mind during their dialog with salespeople.
Our findings also suggest that it is important for marketers to involve sales personnel in strategy creation activities and make concerted efforts to show them the bigger picture - that is, how their ideas fit in the broader scheme of things. Marketers must also understand that, at the end of the day, salespeople want to achieve their sales targets. They look at marketers to add value to their day-to-day activities and position them for success in the marketplace. Hence, marketing managers should make concerted efforts to identify various avenues for adding this value.

Strategy absorption time, one of the contextual conditions we identify, needs special attention from marketers when it comes to getting sales buy-in. Our findings indicate that marketers should give salespeople adequate time to digest and think through new ideas. Accordingly, when planning major initiatives, it would help if marketers involve sales personnel from the beginning, and introduce key ideas early in the process, so they have enough time to think about them. This will also ensure that marketers get well thought-out feedback from sales.

Last, our findings suggest that getting sales buy-in must encompass all levels within the sales and marketing hierarchies. This implies that when strategy implementation faces a challenge, marketers must identify which level within the sales hierarchy is not buying into the strategy and work toward resolving the issues.

\section{Limitations and Future Research Directions}

Before concluding, we wish to mention certain limitations of this study. We collected data for this study through in-depth interviews. If we had observed our informant organizations in situ for an extended period, it is plausible that deeper insights into this phenomenon might have emerged. One may construe the sample size of 49 as a possible limitation. However, we wish to note that qualitative studies in marketing literature (e.g., Beverland, Steel, and Dapiran 2006; Flint, Woodruff, and Gardial 2002) have utilized much smaller sample sizes. In addition, the grounded theory framework guided our data collection effort, and we stopped collecting data upon reaching "theoretical saturation" when no further insights emerged from the interviews (Corbin and Strauss 2008, ch. 7). We would also like to note that the sheer size of the sample is less important than maximized variance. We tried to maximize the variance in responses by selecting a diverse set of informants from both sales and marketing functions. Further, our informants represented a wide range of industries, job functions, and organizational hierarchy.

There are many opportunities for future research. Streams of literature such as internal marketing and the sales-marketing interface have alluded to the notion of sales buy-in rather disjointedly. More work is needed to develop a better understanding of buy-in. In this paper, we identified several concepts related to buy-in. However, for 
future research, it is important to understand the intricacies and interrelationships among these concepts.

It is also useful to study what initiatives firms could implement to obtain greater involvement of salespeople in strategy creation. Further, what could firms do to eliminate interfunctional silos and bridge the cultural divide between sales and marketing? With respect to the sales-marketing interface research, scholars may examine how, and to what extent, sales buy-in of specific marketing strategies contributes to the overall sales-marketing integration within firms. Relatedly, questions such as whether buy-in of a particular strategy guarantees implementation success, or if buy-in of a strategy affects salespeople's perceptions of the subsequent marketing strategies, would also be interesting to investigate.

\section{Conclusion}

The notion of sales buy-in plays an important role in bridging the internal marketing and sales-marketing interface literatures. Although obtaining buy-in from sales is implicitly assumed for sales-marketing integration and effective marketing strategy implementation, its role has not been explicitly studied in the literature. In this paper, we use the grounded theory method to investigate what constitutes sales buy-in, what the organizational determinants of buy-in are, and what factors influence whether marketers may achieve buy-in or not. Our findings serve as a starting point, and we hope they stimulate further research on this topic.

\section{REFERENCES}

Aberdeen Group (2002), "Bridging the Divide: Process, Technology, and the Marketing/Sales Interface," Marketing View Point, 15, 10 (October 4), 1-12.

Ahmed, Pervaiz K., and Mohammed Rafiq (2003), “Internal Marketing Issues and Challenges," European Journal of Marketing, 37 (9), 1177-1186.

Bechky, Beth A. (2006), "Gaffers, Gofers, and Grips: RoleBased Coordination in Temporary Organizations," Organization Science, 17 (1), 3-21.

Bendapudi, Neeli, and Robert P. Leone (2002), “Managing Business-to-Business Customer Relationships Following Key Contact Employee Turnover in a Vendor Firm," Journal of Marketing, 66 (4), 83-101.

Berry, Leonard L. (1981), "The Employee as a Customer," Journal of Retail Banking, 3 (3), 33-40.

Beverland, Michael, Marion Steel, and G. Peter Dapiran (2006), "Cultural Frames That Drive Sales and Marketing Apart: An Exploratory Study," Journal of Business $\mathcal{E}$ Industrial Marketing, 21 (6), 386-394.

Carpenter, Philip (1992), “Bridging the Gap Between Marketing and Sales," Sales and Marketing Management, 144 (March), 29-31.
Cespedes, Frank V. (1993), “Coordinating Sales and Marketing in Consumer Goods Firm," Journal of Consumer Marketing, 10 (2), 37-55.

Carpenter, Philip (1996), "Beyond Teamwork: How the Wise Can Synchronize," Marketing Management, 5 (Spring), 24-37.

Corbin, Juliet, and Anselm Strauss (2008), Basics of Qualitative Research, 3d ed., Los Angeles, CA: Sage.

Corley, Kevin G., and Dennis A. Gioia (2004), "Identity Ambiguity and Change in the Wake of a Corporate SpinOff," Administrative Science Quarterly, 49 (2), 173-208.

Creswell, John W. (2007), Qualitative Inquiry \& Research Design, 2d ed., Thousand Oaks, CA: Sage.

Cross, Rob, and Lee Sproull (2004), "More Than an Answer: Information Relationships for Actionable Knowledge," Organization Science, 15 (4), 446-462.

Dawes, Philip L., and Graham R. Massey (2006), “A Study of Relationship Effectiveness Between Marketing and Sales Managers in Business Markets," Journal of Business $\mathcal{E}$ Industrial Marketing, 21 (6), 346-360.

Day, George S. (1994), "The Capabilities of Market-Driven Organizations," Journal of Marketing, 58 (10), 37-52.

Deshpande, Rohit (1983), “'Paradigms Lost': On Theory and Method in Research in Marketing," Journal of Marketing, 47 (Fall), 101-110.

Dewsnap, Belinda, and David Jobber (2000), “The SalesMarketing Interface in Consumer Packaged-Goods Companies: A Conceptual Framework," Journal of Personal Selling E Sales Management, 20, 2 (Spring), 109-119.

Dewsnap, Belinda, and David Jobber (2002), “A Social Psychological Model of Relations Between Marketing and Sales," European Journal of Marketing, 36 (7-8), 874-894.

Donath, Bob (1999), “Get Marketing, Sales on Same Wavelength," Marketing News (September 16), 16.

Emans, B. (2004), Interviewing: Theory, Techniques and Training, Groningen/Houten: Wolters-Noordhoff.

Flint, Daniel J., Robert B. Woodruff, and Sarah F. Gardial (2002), "Exploring the Phenomenon of Customers' Desired Value Change in a Business-to-Business Context," Journal of Marketing, 66 (10), 102-117.

Frost, Frederick A., and Mukesh Kumar (2000), "INTSERVQUAL-An Internal Adaptation of the GAP Model in a Large Service Organization," Journal of Services Marketing, 14 (415), 358-376.

Glaser, Barney G., and Anselem L. Strauss (1967), The Discovery of Grounded Theory, Chicago: Aldine.

Gounaris, Spiros P. (2006), "Internal-Market Orientation and Its Measurement," Journal of Business Research, 59 (4), 432-448.

Gronroos, Christian (1983), "Strategic Management and Marketing in the Service Sector," Report no. 83-104, Marketing Science Institute, Cambridge, MA.

Guenzi, Paolo, and Gabriele Troilo (2007), "The Joint Contribution of Marketing and Sales to the Creation of Superior Customer Value," Journal of Business Research, 60 (2), 98-107. 
Gummesson, Evert (2003), "All Research Is Interpretive!" Journal of Business \& Industrial Marketing, 18 (6-7), 482-492.

Homburg, Christian, and Ove Jensen (2007), "The Thought Worlds of Marketing and Sales: Which Differences Make a Difference?" Journal of Marketing, 71 (July), 124-142.

Homburg, Christian, and Christian Pflesser (2000), "A Multiple-Layer Model of Market-Oriented Organizational Culture: Measurement Issues and Performance Outcomes," Journal of Marketing Research, 37 (4), 449-462.

Homburg, Christian, Ove Jensen, and Harley Krohmer (2008), "Configurations of Marketing and Sales: A Taxonomy," Journal of Marketing, 72 (March), 133-154.

Hurley, Robert F. (1998), “Customer Service Behavior in Retail Settings: A Study of the Effect of Service Provider Personality," Academy of Marketing Science Journal, 26 (2), 115-127.

Ingram, Thomas N. (2004), "Future Themes in Sales and Sales Management: Complexity, Collaboration, and Accountability," Journal of Marketing Theory \& Practice, 12 (Fall), 18-28.

Kirca, Ahmet H., Satish Jayachandran, and William O. Bearden (2005), "Market Orientation: A Meta-Analytic Review and Assessment of Its Antecedents and Impact on Performance," Journal of Marketing, 69 (2), 24-41.

Kohli, Ajay K., and Bernard J. Jaworski (1990), "Market Orientation: The Construct, Research Propositions, and Managerial Implications," Journal of Marketing, 54 (4), $1-18$.

Kotler, Philip, Neil Rackham, and Suj Krishnaswamy (2006), "Ending the War Between Sales and Marketing," Harvard Business Review, 84 (718), 68-78.

LeMeuneir-FitzHugh, Ken, and Nigel Piercy (2007), “Does Collaboration Between Sales and Marketing Affect Business Performance?" Journal of Personal Selling $\mathcal{E}$ Sales Management, 27, 3 (Summer), 207-220.

Lincoln, Yvonna S., and Egon E. Guba (1985), Naturalistic Inquiry, Beverly Hills, CA: Sage.

Lings, Ian N. (2004), "Internal Market Orientation: Construct and Consequences," Journal of Business Research, 57 (4), 405-413.

Lings, Ian N., and Gordon E. Greenley (2005), "Measuring Internal Market Orientation," Journal of Service Research, 7 (2), 290-305.

Lorge, Sarah (1999), "Marketers Are From Mars, Salespeople Are From Venus," Sales and Marketing Management, 151 (4), 26-33.

Maltz, Elliot, and Ajay K. Kohli (1996), "Market Intelligence Dissemination Across Functional Boundaries," Journal of Marketing Research, 33 (2), 47-61.

Massey, Graham R., and Philip L. Dawes (2007), "Personal Characteristics, Trust, Conflict, and Effectiveness in Marketing/ Sales Working Relationships," European Journal of Marketing, 41 (9-10), 1117-1145.
Matthyssens, Paul, and Wesley J. Johnston (2006), "Marketing and Sales: Optimization of a Neglected Relationship," Journal of Business \& Industrial Marketing, 21 (6), 338-345.

McCracken, Grant (1988), The Long Interview, Newbury Park, CA: Sage.

Menon, Ajay, Barnard J. Jaworski, and Ajay K. Kohli (1996), "Product Quality: Impact of Interdepartmental Interactions," Journal of the Academy of Marketing Science, 25 (3), 187-200.

Montgomery, David, and Frederick E. Webster, Jr. (1997), "Marketing's Interfunctional Interfaces: The MSI Workshop of Management of Corporate Fault Zones," Journal of Market Focused Management, 2 (1), 7-26.

Narver, John C., and Stanley F. Slater (1990), “The Effect of a Market Orientation on Business Profitability," Journal of Marketing, 54 (4), 20-35.

Naudé, Pete, Janine Desai, and John Murphy (2003), “Identifying the Determinants of Internal Marketing Orientation," European Journal of Marketing, 37 (9), 1205-1220.

Noble, Charles H., and Michael P. Mokwa (1999), "Implementing Marketing Strategies: Developing and Testing a Managerial Theory," Journal of Marketing, 63 (4), 57-73.

Oliva, Ralph A. (2006), “The Three Key Linkages: Improving the Connections Between Marketing and Sales," Journal of Business \& Industrial Marketing, 21 (6), 395-398.

Olson, Eric M., Stanley F. Slater, and G. Tomas M. Hult (2005a), "The Importance of Structure and Process to Strategy Implementation," Business Horizons, 48 (1), $47-54$.

Olson, Eric M., Stanley F. Slater, and G. Tomas M. Hult (2005b), "The Performance Implications of Fit Among Business Strategy, Marketing Organization Structure, and Strategic Behavior," Journal of Marketing, 69 (3), 49-65.

Panigyrakis, George C., and Cleopatra A. Veloutsou (1999), "Brand Managers' Interfaces in Different Consumer Goods Industries," Journal of Product and Brand Management, 8 (1), 19-37.

Piercy, Nigel F. (2006), “The Strategic Sales Organization," Marketing Review, 6 (Spring), 3-28.

Piercy, Nigel F., and Nikala Lane (2003), "Transformation of the Traditional Salesforce: Imperatives for Intelligence, Interface and Integration," Journal of Marketing Management, 19 (7), 563-582.

Piercy, Nigel F., and Neil Morgan (1995), "Internal Marketing-The Missing Half of the Marketing Programme," Long Range Planning, 24 (2), 82-93.

Rackham, Neil, and John DeVincentis (1999), Rethinking the Sales Force: Redefining Selling to Create and Capture Customer Value, New York: McGraw-Hill.

Rafiq, Mohammed, and Pervaiz K. Ahmed (1993), "The Scope of Internal Marketing: Defining the Boundary Between Marketing and Human Resource Management," Journal of Marketing Management, 9 (7), 219-232. 
Rafiq, Mohammed, and Pervaiz K. Ahmed (2000), "Advances in the Internal Marketing Concept: Definition, Synthesis and Extension," Journal of Services Marketing, 14 (617), 449-462.

Reynoso, Javier F., and Brian Moores (1996), "Internal Relationships," in Relationship Marketing: Theory and Practice, F. Buttle, ed., London: Paul Chapman, pp. 55-73.

Rouziès, Dominique, Erin Anderson, Ajay K. Kohli, Ronald E. Michaels, Barton A. Weitz, and Andris A. Zoltners (2005), "Sales and Marketing Integration: A Proposed Framework," Journal of Personal Selling \& Sales Management, 25, 2 (Spring), 113-122.

Ruekert, Robert W., and Orville C. Walker, Jr. (1987), “Marketing's Interaction with Other Functional Units: A Conceptual Framework and Empirical Evidence," Journal of Marketing, 51 (1), 1-19.

Rust, Roland T., and Bruce Cooil (1994), "Reliability Measures for Qualitative Data: Theory and Implications," Journal of Marketing Research, 31 (1), 1-14.

Sasser, W. Earl, and Stephen P. Arbeit (1976), “Selling Jobs in the Service Sector," Business Horizons, 19 (6), 61-65.

Silverman, David, and Aamir Marvasti (2008), Doing Qualitative Research: A Comprehensive Guide, Thousand Oaks, CA: Sage.

Singh, Jagdip (1998), "Striking a Balance in Boundary-Spanning Positions: An Investigation of Some Unconventional Influences of Role Stressors and Job Characteristics on Job Outcomes of Salespeople," Journal of Marketing, 62 (7), 69-86.

Srivastava, Rajendra K., Tasadduq A. Shervani, and Liam Fahey (1999), "Marketing, Business Processes, and Shareholder Value: An Organizationally Embedded View of Marketing Activities and the Discipline of Marketing," Journal of Marketing, 63 (4), 168-179.
Strahle, William M., Rosann L. Spiro, and Frank Acito (1996), "Marketing and Sales: Strategic Alignment and Functional Implementation," Journal of Personal Selling \& Sales Management, 16, 1 (Winter), 1-20.

Strauss, Anselm, and Juliet Corbin (1998), Basics of Qualitative Research: Techniques and Procedures for Developing Grounded Theory, Thousand Oaks, CA: Sage.

Tansuhaj, Patriya, Donna Randall, and Jim McCullough (1988), "A Services Marketing Management Model: Integrating Internal and External Marketing Functions," Journal of Services Marketing, 2 (1), 31-38.

Thompson, Craig J., Aric Rindfleisch, and Zeynep Arsel (2006), "Emotional Branding and the Strategic Value of the Doppelganger Brand Image," Journal of Marketing, 70 (1), 50-64.

Tuli, Kapil R., Ajay K. Kohli, and Sundar G. Bharadwaj (2007), "Rethinking Customer Solutions: From Product Bundles to Relational Processes," Journal of Marketing, 71 (7), 1-17.

Varadarajan, P. Rajan, Satish Jayachandran, and J. Chris White (2001), "Strategic Interdependence in Organizations: Deconglomeration and Marketing Strategy," Journal of Marketing, 65 (1), 15-28.

Wasmer, D.J., and Gordon C. Brunner, II (1991), “Using Organizational Culture to Design Internal Marketing Strategies," Journal of Services Marketing, 5 (1), 35-46.

Workman, John P., Jr., Christian Homburg, and Kjell Gruner (1998), "Marketing Organization: An Integrative Framework of Dimensions and Determinants," Journal of Marketing, 62 (7), 21-41.

Yandle, Jo, and Jim Blythe (2000), "Intra-Departmental Conflict Between Sales and Marketing: An Exploratory Study," Journal of Selling and Major Account Management, 2 (3), 3-31.

\section{APPENDIX}

\section{Interview Questions}

Why is getting a buy-in from the sales force of a marketing strategy important?

What are the benefits of getting buy-in from the sales force?

Why do some companies succeed in getting a buy-in? Why do some firms not succeed in this endeavor?

What does getting a buy-in from the sales force entail?

What happens if marketing fails to get a buy-in from sales?

Are there any other factors that may determine whether sales embraces the marketing initiatives? 